\title{
A Facile Synthesis of Lipophilic Acetal Derivatives of L-Ascorbic Acid (Vitamin C)
}

\author{
Toshiyuki KIDA, Araki MASUYAMA, and Yohji NAKATSUJI* \\ Department of Applied Chemistry, Faculty of Engineering, Osaka University \\ (2-1, Yamadaoka, Suita-shi, ₹565)
}

\begin{abstract}
5,6-O-Alkylidene- or alkenylidene- $\mathrm{L}^{-}$-ascorbic acids were prepared by the transacetalization of $\mathrm{L}^{-}$ ascorbic acid with aliphatic aldehyde or ketone dimethyl acetal in good yield. The isolated products derived from aldehyde dimenthyl acetal were found to consist of a mixture of two diastereomers (ratio, $\sim 1: 1$ ) based on the results of NMR spectroscopic analysis.
\end{abstract}

\section{Introduction}

Recently, L-ascorbic acid (vitamin C) has been used in widespread fields as food additives, pharmaceuticals and cosmetics. However, it is easily oxidized and unstable to both light and heat because of its specific structure, 2,3-endiol. Therefore, it is difficult to convert $\mathrm{L}$-ascorbic acid into the lipophilic derivatives which show high solubility in organic solvents, and only a few reports have described the reaction of $\mathrm{L}$-ascorbic acid with long-chain aliphatic compounds ${ }^{1) \sim 3)}$. The higher fatty acid monoesters of $\mathrm{L}$-ascorbic acid are representative lipophilic derivatives of $\mathrm{L}^{-}$-ascorbic acid and they are known to have vitamin activities similar to L-ascorbic acid ${ }^{4), 5)}$. Especial$\mathrm{ly}$, it is noteworthy that $6-\mathrm{O}^{- \text {palmitoyl- } \mathrm{L}^{-}}$ ascorbic acid exhibits higher antitumor activity than $\mathrm{L}^{-}$ascorbic acid ${ }^{6), 7)}$.

In this work we report a facile synthetic method for new lipophilic acetal derivatives of L-ascorbic acid, which are expected to be alternatives to the higher fatty acid monoesters of L-ascorbic acid and to be applicable to medical and biological fields. Concerning the acetal derivatives of ascorbic acid, 5,6-O-isopropylidene- $\mathrm{L}^{-}$ ascorbic acid $^{8)}, 5,6-O$-benzylidene-L-ascorbic acid $^{9)}$ and 5,6-O-cyclohexylidene- $\mathrm{D}^{-}$ isoascorbic acid ${ }^{10)}$ have been synthesized before. However, we found that those synthetic

Corresponding author : Yohji Nakatsuji methods gave the desired long-chain alkyl or alkenyl acetal derivatives only in poor yields $(<10 \%)$.

\section{Experimental}

All reagents were of reagent grade and were used without further purification except DMF, which was dried over molecular sieves $4 \mathrm{~A}$ before use. IR spectra were recorded on a Hitachi infrared spectrometer 260-10. NMR spectra were recorded on a JEOL JNM-GSX 400 spectrometer with TMS as an internal standard. Mass spectra were recorded on a JEOL JMS-DX $303 \mathrm{HF}$ spectrometer. Elemental analyses were obtained using a Perkin-Elmer $240 \mathrm{C}$ analyzer. TLC was done on silica gel (Merck Silica 60 $\mathrm{F}_{254}$ sheets). Typical synthetic procedures are as follows :

5,6-O-Octylidene-L-ascorbic acid 2a : A mixture of L-ascorbic acid $(4.23 \mathrm{~g}, 24$ mmol), 1,1-dimethoxyoctane 1a (3.49 g, 20 $\mathrm{mmol}), p$-toluenesulfonic acid monohydrate (0.76 g, $4 \mathrm{mmol})$, DMF (20 mL) and $n$-hexane $(30 \mathrm{~mL})$ was placed in a round-bottom flask equipped with a Dean-Stark trap. The mixture was refluxed for $7 \mathrm{~h}$; approximately $1 \mathrm{~mL}$ of methanol was collected in the Dean-Stark trap. After addition of sodium hydroxide $(0.16 \mathrm{~g}, 4 \mathrm{mmol})$ in methanol (5 $\mathrm{mL}$ ) at room temperature to neutralize $p^{-}$ toluenesulfonic acid, the solvent was evaporated off in vacuo. The residue was extracted with brine $(50 \mathrm{~mL})$ and $\mathrm{Et}_{2} \mathrm{O}(3 \times 80 \mathrm{~mL})$. 
The organic layer was dried over anhydrous magnesium sulfate and concentrated. The crude product was purified by recrystallization from benzene (76 \% yield, mp 128 130 $\left.{ }^{\circ} \mathrm{C}\right)$. The isolated product was found to consist of a mixture of two diastereomers (ratio, $1: 1$ ) by the NMR spectroscopic analyses. Analytical data for compound 2a are as follows : IR ( $\mathrm{KBr})$ : 3420, 3050, 2930, 2850, $1760,1680,1470,1330,1130 \mathrm{~cm}^{-1}$. Mass $[\mathrm{m} / e$, rel. intens. ] : $286\left[\mathrm{M}^{+}, 4\right], 187[100], 171[35]$, $141[36], \quad 111[35], \quad 69[57] .{ }^{1} \mathrm{H}-\mathrm{NMR}$ [acetone- $\mathrm{d}_{6}$, TMS as an internal standard, $\delta, J$ $(\mathrm{Hz})]$ : Diastereomer A ; $0.88(\mathrm{t}, 3 \mathrm{H}, J=$ $6.8), 1.28-1.38(\mathrm{~m}, 10 \mathrm{H}), 1.54-1.60(\mathrm{~m}, 2 \mathrm{H})$, $3.90(\mathrm{dd}, 1 \mathrm{H}, J=7.3,8.3), 4.26(\mathrm{dd}, 1 \mathrm{H}, J=7$, $8.5), 4.34(\mathrm{~m}, 1 \mathrm{H}), 4.76(\mathrm{~d}, 1 \mathrm{H}, J=2.9), 4.89$ $(\mathrm{t}, 1 \mathrm{H}, J=4)$. Diastereomer B ; $0.88(\mathrm{t}, 3 \mathrm{H}$, $J=6.8), \quad 1.28-1.38(\mathrm{~m}, 10 \mathrm{H}), \quad 1.54-1.60(\mathrm{~m}$, $2 \mathrm{H}), 3.99(\mathrm{dd}, 1 \mathrm{H}, J=7.3,8.3), 4.06(\mathrm{dd}, 1 \mathrm{H}$, $J=5.4,8.3), 4.32(\mathrm{~m}, 1 \mathrm{H}), 4.72(\mathrm{~d}, 1 \mathrm{H}, J=$ 3.9), 4.87 (t, $1 \mathrm{H}, J=4)$.

\section{Results and Discussion}

First, L-ascorbic acid was allowed to react with an appropriate aliphatic aldehyde or ketone in DMF-benzene, in the presence of $p$-toluenesulfonic acid, under reflux conditions in order to eliminate condensed water into the Dean-Stark trap. In this case the desired 5,6-O-alkylidene- or alkenylidene-L-ascorbic acids were obtained in low yields, perhaps because L-ascorbic acid and the resulting acetal derivatives, which were both very heat-labile, decomposed to a considerable extent. So carbonyl compounds were preliminarily converted into the corresponding dimethyl acetals, and the target acetal compounds were synthesized under milder conditions using transacetalization of the dimethyl acetals with L-ascorbic acid. The dimethyl acetal derivatives 1 were almost quantitatively prepared according to the previously reported method ${ }^{11), 12)}$. These acetals 1 were made to react with $\mathrm{L}^{-}$ascorbic acid in DMF- $n$-hexane at the reflux temperature, as illustrated in Fig. - 1. Methanol generated during the reaction was removed into the Dean-Stark trap. The yields of products are shown in Table-1.

Compared with the first method, this method using transacetalization gave the desired compounds in better yields. The real yields of compounds $2 \mathrm{a} \sim \mathrm{g}$ should be much higher than the isolated yields reported in the Table, judging from TLC analyses of the crude products. However, a slight amount of DMF, the unreacted dimethyl acetals or carbonyl compounds generated by hydrolysis of 1 caused lowering of the yields purified by recrystallization. Especially for the products $2 \mathrm{e} \sim \mathrm{g}$ derived from ketone dimethyl acetals, it was very difficult to completely remove the unreacted 1 from the crude compounds before recrystallization, and so their isolated yields became lower than those of the compounds $2 \mathbf{a} \sim \mathbf{d}$ derived from aldehyde dimethyl acetals. The ${ }^{1} \mathrm{H}-$ $\mathrm{NMR},{ }^{13} \mathrm{C}-\mathrm{NMR}, \mathrm{H}-\mathrm{H}$ COSY and $\mathrm{C}-\mathrm{H}$ COSY spectra of compounds derived from aldehyde dimethyl acetals $(\mathbf{2} \mathbf{a} \sim \mathbf{d})$ indicated that they consisted of a mixture of two diastereomers (ratio, $\sim 1: 1$ ) which had different configurations at the acetal carbon atom on the 1,3-dioxolane ring. On the contrary, all spectral data showed that the isolated $2 \mathrm{e} \sim \mathrm{g}$ derived from ketone dimethyl acetals apparently comprised only one diastereomer, although the presence of other diastereomers in the crude products should

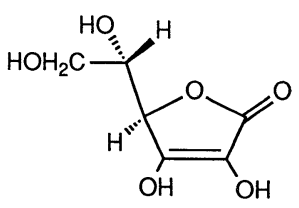

L-Ascorbic acid

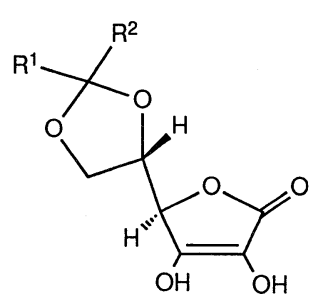

2a g

Fig.-1 Preparation of acetal derivatives of $\mathrm{L}$-ascorbic acid. 
Table-1 Yields and elemental analyses of compounds $2 \mathrm{a} \sim \mathrm{g}$.

\begin{tabular}{|c|c|c|c|c|}
\hline Compound & $\mathrm{R}^{1}$ & $\mathrm{R}^{2}$ & $\begin{array}{l}\text { Yield }^{a)} \\
\%\end{array}$ & $\begin{array}{c}\text { E.A. }{ }^{\text {b) }} \\
\text { Found (Calcd.) }\end{array}$ \\
\hline $2 a$ & $\mathrm{C}_{7} \mathrm{H}_{15}$ & $\mathrm{H}$ & $76(46)$ & $\begin{array}{l}\mathrm{C}: 56.66(56.94) \\
\mathrm{H}: \quad 7.67(7.85)\end{array}$ \\
\hline $2 b$ & $\mathrm{C}_{11} \mathrm{H}_{23}$ & $\mathrm{H}$ & $65(32)$ & $\begin{array}{l}\mathrm{C}: 61.23(61.52) \\
\mathrm{H}: \quad 8.55(8.89)\end{array}$ \\
\hline $2 c$ & $\mathrm{CH}_{2}=\mathrm{CH}\left(\mathrm{CH}_{2}\right)_{8}$ & $\mathrm{H}$ & $58(26)$ & $\begin{array}{l}\mathrm{C}: 60.63(60.88) \\
\mathrm{H}: 8.12(8.11)\end{array}$ \\
\hline $2 d^{c)}$ & $\mathrm{R}^{\mathrm{C}}$ & $\mathrm{H}$ & $50(30)$ & $\begin{array}{l}\mathrm{C}: 60.92(61.52) \\
\mathrm{H}: \quad 7.75(7.74)\end{array}$ \\
\hline $2 \mathrm{e}$ & $\mathrm{C}_{6} \mathrm{H}_{13}$ & $\mathrm{CH}_{3}$ & $48(27)$ & $\begin{array}{l}\mathrm{C}: 58.66(58.73) \\
\mathrm{H}: 7.40(7.74)\end{array}$ \\
\hline $2 \mathrm{f}$ & $\mathrm{C}_{11} \mathrm{H}_{23}$ & $\mathrm{CH}_{3}$ & $47(21)$ & $\begin{array}{l}\mathrm{C}: 63.75(64.02) \\
\mathrm{H}: \quad 8.93(9.05)\end{array}$ \\
\hline $2 g^{d)}$ & $\mathrm{R}^{\mathrm{G}}$ & $\mathrm{CH}_{3}$ & $35(22)$ & $\begin{array}{l}\mathrm{C}: 64.46(64.75) \\
\mathrm{H}: \quad 7.98(8.00)\end{array}$ \\
\hline
\end{tabular}

a) Isolated yields. Yields in parentheses are ones obtained by the reactions of $\mathrm{L}$-ascorbic acid with aliphatic aldehyde or ketone.

b) Calculated values for $\mathbf{2} \mathbf{a} \sim \mathbf{d}$ are based on the assumption that these contain $0.5 \mathrm{~mol}$ of water.

c) $\mathrm{R}^{\mathrm{C}}:\left(\mathrm{CH}_{3}\right)_{2} \mathrm{C}=\mathrm{CH}\left(\mathrm{CH}_{2}\right)_{2} \mathrm{CH}\left(\mathrm{CH}_{3}\right) \mathrm{CH}_{2}$

d) $\mathrm{R}^{\mathrm{G}}:\left(\mathrm{CH}_{3}\right)_{2} \mathrm{C}=\mathrm{CH}\left(\mathrm{CH}_{2}\right)_{2} \mathrm{C}\left(\mathrm{CH}_{3}\right)=\mathrm{CH}\left(\mathrm{CH}_{2}\right)_{2}$

be possible.

(Received May 25, 1994)

\section{References}

1) D. Swern, A.J. Stirton, J. Turer, and P.A. Wells, Oil and Soap, 20, 224 (1943).

2) H.A. Staab and A. Mannschreck, Chem. Ber., 95, 1293 (1962).

3) H. Tanaka and R. Yamamoto, YAKUGAKU ZASSHI, 86, 376 (1966).

4) C. Inagaki and K. Kawaguchi, Vitamine, 34, 293 (1965).

5) O.G. Fitzhugh and A.A. Nelson, Proc. Soc. Exp. Biol. Med., 61, 195 (1946).

6) N. Miwa and H. Yamazaki, Exptl. Cell Biol., 54, 245 (1986).

7) N. Miwa, H. Yamazaki, Y. Nagaoka, K. Kageyama, Y. Onoyama, I. Matsui-Yuasa, S. Otani, and S. Morisawa, Biochim. Biophys. Acta, 972, 144 (1988).

8) M.E. Jung and T.J. Shaw, J. Am. Chem. Soc., 102, 6304 (1980).

9) R.W. Atchley and B.M. Tolbert, Org. Prep. Proced. Int., 3, 299 (1971).
10) A. Tanaka and K. Yamashita, Synthesis, 1987, 570 .

11) G. Büchi, P. Kulsa, and R.L. Rosati, J. Am. Chem. Soc., 90, 2448 (1968).

12) T. Kida, N. Morishima, A. Masuyama, and Y. Nakatsuji, J. Am. Oil Chem. Soc., in press.

\section{L-アスコルビン酸の親油性アセタール 誘導体の簡便な合成}

\section{木田敏之・益山新樹・中过洋司}

\section{大阪大学工学部応用化学科 (₹565 吹田市山田丘 2-1)}

脂肪族アルデヒド及びケトンのジメチルアセタールと L-アスコルビン酸とのアセタール交換反応により， 5 , 6-O-アルキリデン-及びアルケニリデン-L-アスコルビ ン酸を良好な収率で合成した。NMR 分光分析により, アルデヒドジメチルアセタール由来の単離生成物は 2 種 のジアステレオマー(存在比 約 $1: 1$ ) の混合物である ことがわかった。

（連絡者：中辻洋司） 